\title{
RETINAL PIGMENT EPITHELIUM TEARS IN YOUNGER PATIENTS: CAUSES AND CONSEQUENCES
}

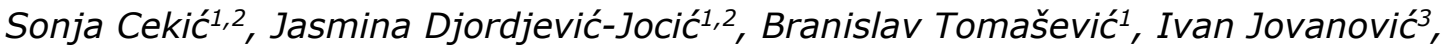 \\ Predrag Jovanović1,2, Milena Vujanović ${ }^{1}$
}

\begin{abstract}
We present three different cases of patients with retinal pigment epithelium (RPE) tear: one case with choroidal osteoma, one with central serous chorioretinopathy (CSHR) and one with idiopathic polypoidal vasculopathy (IPCV). Fotodocumentation, fluorescein angiography, optical coherence tomography (OCT) and OCT angiography showed typical choroidal neovascularization in patient with osteoma and IPCV. In patient with CSHR, large PED without choroidal neovascularization was present. PED tear was detected in all patients.

Various eye disorders, such as tear of retinal pigment layer, can complicate clinical picture and be associated with PED. Large height and diameter of PED, association with CNV, small ratio of CNV size to PED size, lines in infrared images, and duration of PED may predict the course of RPE tear. Therefore, it should be monitored for this complication. Treatment and outcome depends on cause of tear.
\end{abstract}

Acta Medica Medianae 2020;59(1):133-138.

Key words: retinal pigment epithelium, tears, causes

${ }^{1}$ Clinic for Eye Diseases, Clinic Center Niš, Serbia

${ }^{2}$ University of Niš, Faculty of Medicine, Department of

Ophthalmology, Serbia

${ }^{3}$ University of Niš, Faculty of Medicine, Department of Anatomy and Clinical Anatomy, Serbia

Contact: Sonja Cekić

48 Dr. Zoran Djindjić Blvd., 18000 Niš, Serbia

E-mail: sonjaziv@yahoo.com
The aim of our study was to present three different cases with the tear of RPE. The first patient was with central serous chorioretinopathy (CSHR), the second was with choroidal osteoma and the third with idiopathic polypoidal vasculopathy (IPCV). In such way, we want to emphasize that different etiology, then pathophysiological bases can underpin tear of RPE, and to estimate possible risk factors for its development.

\section{First case}

A 33 year old male presented with metamorphosia, blurred central vision and small decrease of visual acuity, a disturbance of color vision in the left eye presented as a dark spot in the central vision. Visual acuity tested by Snellen chart was 1.0 in the right eye and 0.5 in the left eye. Intraocular pressure was $14 \mathrm{mmHg}$ in the right eye and $16 \mathrm{~mm} \mathrm{Hg}$ in the left eye. A slit lamp biomicroscopy showed a normal appearance. Family and life history were negative. The patient suffered from sleep disorders.

A posterior segment examination showed edema of posterior pole between vascular arcade of superior and inferior temporal retinal arterial branches in the left eye (Figure 1a). In the left eye, small area of grey color was noted in the edematous zone close to the superior temporal artery (Figure 1a). The appearance of posterior pole of the right eye was normal. During fluorescein angiography, in the left eye, leaking as point in early phase and in form of umbrella in late phase was present (Figure 1b). OCT of macula on the left eye showed detachment 10, 11). 
of RPE with present tear (Figure 1c). Central macular thickness on retinal maps was $586 \mu \mathrm{m}$.

After two weeks, treatment with topical nonsteroid drops, drops with carbonanhydrase inhibitors and systemic administration of eplerenone $25 \mathrm{mg}$ daily resulted in a smaller edema, which was resorbed after four weeks. Visual acuity restored to 0.9 , by Snellen and small subjective color vision defects persisted for some time.

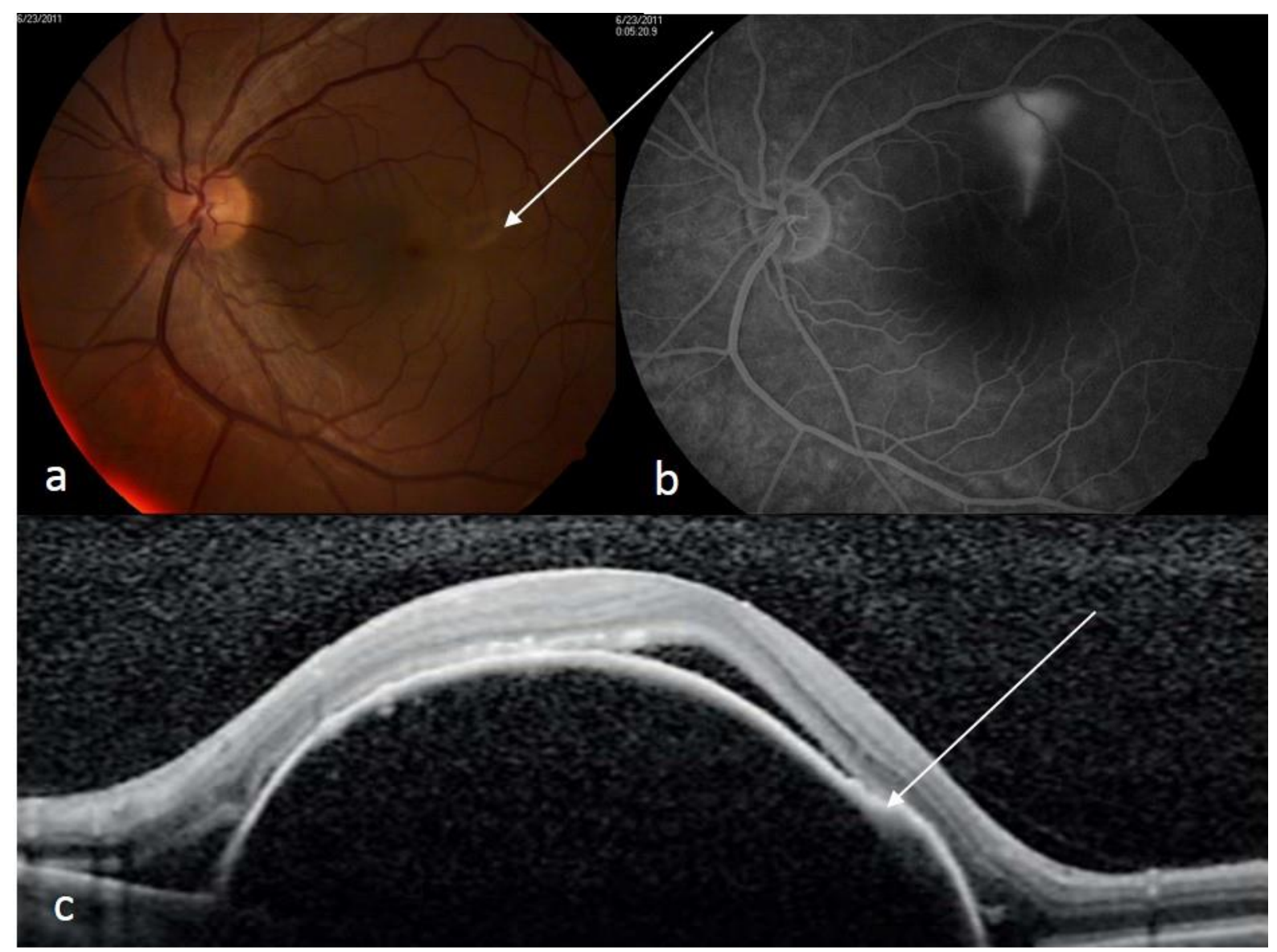

Figure 1. Patient with CSHR

a) Color fundus photography-arrow is pointing to a possible area of RPE tear

b) FA

c) OCT- arrow is pointing to RPE tear

\section{Second case}

A 14 year old girl with abrupt and painless vision loss in the right eye was presented. Family and previous life history were negative. Best corrected visual acuity tested in the right eye was counting fingers on 2 meters, and in the left eye 1.0 by Snellen. Intraocular pressure in both eyes was 14 $\mathrm{mmHg}$. A slit lamp biomicroscopy showed normal appearance.

Posterior segment examination showed slightly and irregularly elevated yellow area with small vascular networks and hemorrhages on its surface (Figure 2a). Dark lines were notable on the surface of the lesion (Figures 2a, b), too. Line defect in the area of osteoma presented RPE tear (Figure 2a). Fluorescein angiography showed blockade of choroidal fluorescence in the zones of hemorrhage in early phase, and hiperfluorescence with leaking and pooling in later phase (Figures $2 c$ and d). Leaking phenomena was caused by the presence of newly formed choroidal vessels (Figures $2 b$ and $c$ ). Ultrasonography B scan presented highly reflective choroidal mass with acoustic shadowing (Figure $2 f$ ). OCT finding proved choroidal neovascularization with RPE tear (Figure 2e).

The patient started with anti VEGF therapy, without significant visual recovery. 


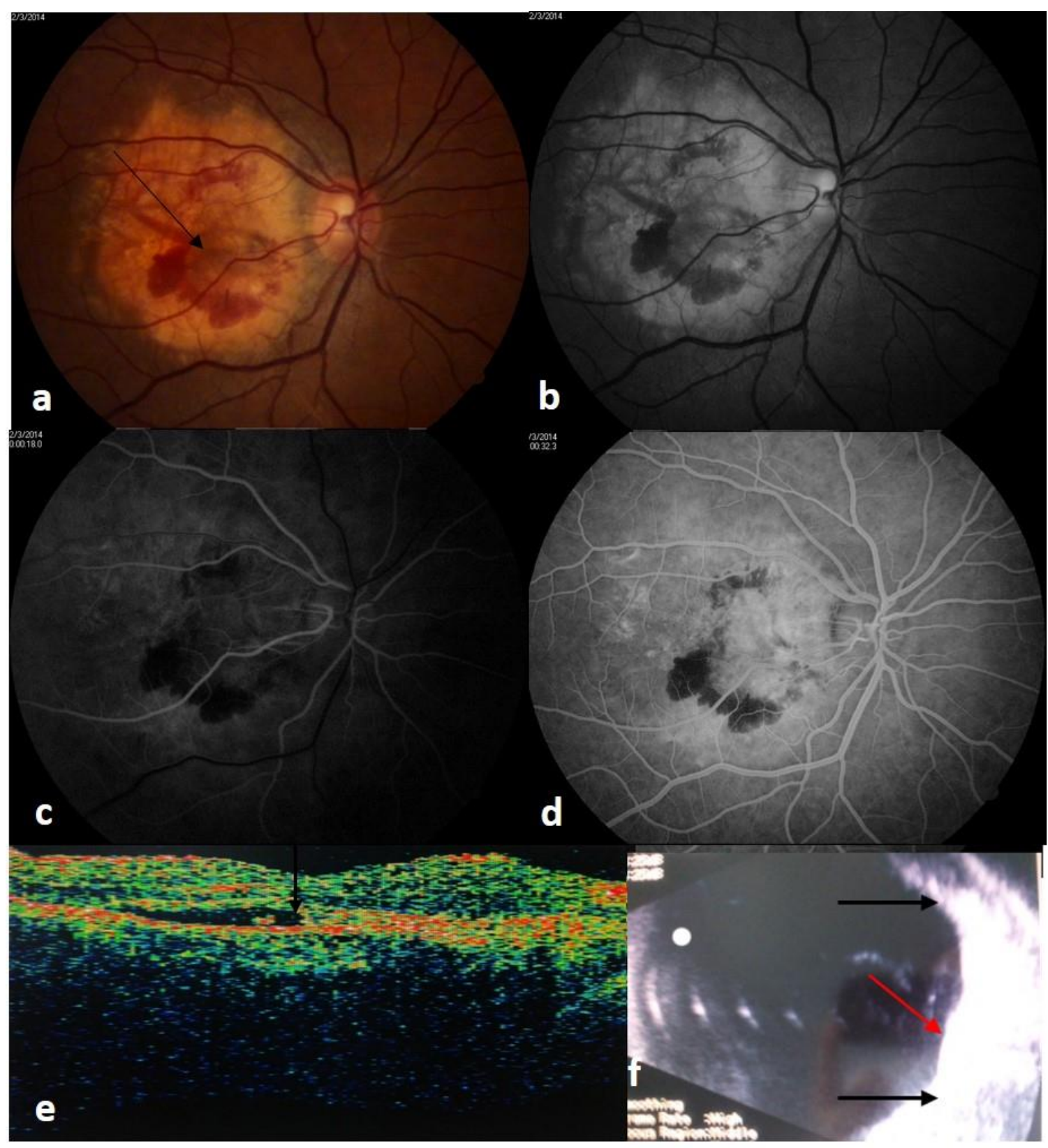

Figure 2. Patient with choroidal osteoma
a) Color fundus photography
b) Fundus photography green mode
c) FA-arrows are pointing to an area of possible RPE tear
d) FA-arrows are pointing to an area of possible RPE tear
e) OCT-arrows are pointing to RPE tear
f) B scan ultrasonography-red arrow is pointing to osteoma and black to secondary effect

\section{Third case}

A 46 year old male, with sudden visual loss in the left eye was presented at the Clinic for Eye Diseases. Family and previous life history were negative. Vision loss was painless and without any other manifestation after a hard workday. Best corrected visual acuity in the left eye was 0.1 by Snellen. Visual acuity in the right eye was preserved.
Intraocular pressure in both eyes was $16 \mathrm{mmHg}$. A slit lamp biomicroscopy showed a normal appearance.

Preretinal hemorrhage and retinal hemorrhage were present in macular and paramacular region, as well as in the area of grey round atrophy of choroid (Figure 3a). Peripapillar atrophy was also noted on fundus photography (Figure 3a). Fluorescein angiography showed blockade of choroidal 
fluorescence in the areas of hemorrhage and point hyperfluorescence during angiography in the area of noted choroidal atrophy (Figure $3 b$ ). On OCT PED and PED small RPE tear was noted (Figure $3 c$ ).
Spontaneous resorption of retinal and preretinal hemorrhages was present and discrete visual improvement with anti-VEGF therapy was noted.

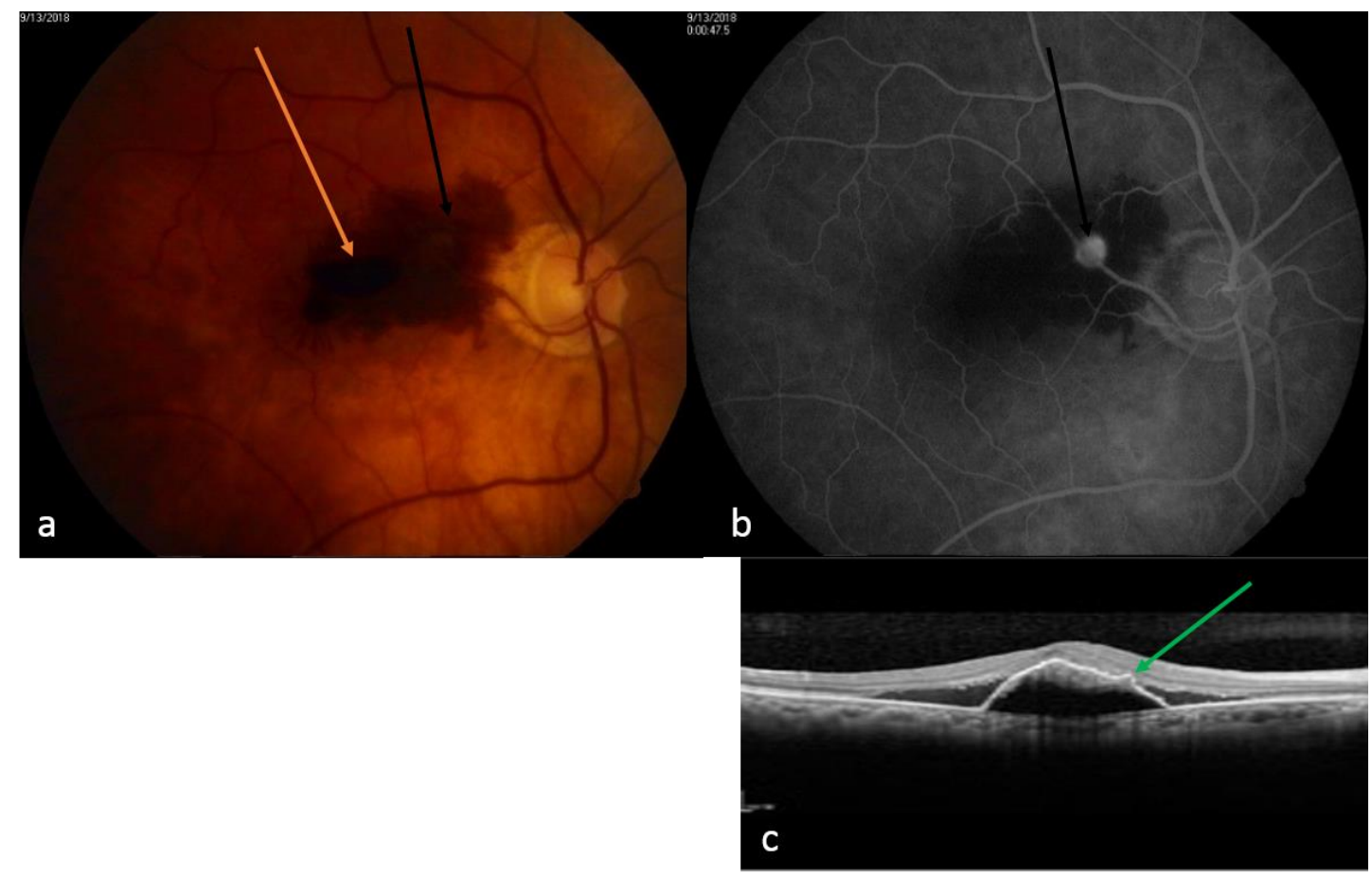

Figure 3. Patient with IPCV

a) Color fundus photography black arrow is pointing to a possible area of tear and red to preretinal hemorrhage

b) FA-arrow is pointing to a possible area of RPE tear

c) OCT-arrow is pointing to a possible area of RPE tear

\section{Discussion}

Hoskin et al. first reported RPE tears as a complication in patients with PED due to AMD (13). Today, it is well known that RPE tear can be part of the natural course of PED due to occult CNV or a complication of different procedures such as: antiVEGF therapy, photodynamic therapy, laser photocoagulation, or transpupillary thermotherapy $(5,6$, 7, 12, 13).

Retinal pigment tear in younger patients is rare. It is described in cases such as: traumatic chorioretinopathy, high myopia, angioid streaks, choroidal tumors, light chain deposition disease, central serous chorioretinopathy, and polypoidal choroidal vasculopathy (PCV), retinal dystrophies and chorioretinitis (posterior uveitis) $(2,3,4,10)$.

We presented young patients with different retinal pathology and associated PED and RPE tear. Possible pathogenetic mechanism of RPE tear in case of patient with CSHR maybe large PED (Figure $1 \mathrm{a}, \mathrm{c})$ and duration of process, which was supported by umbrella leaking during fluorescein angiography (Figure 1). The tear is present in this case at the base of PED, and the possible factor for tear may be pressure of fluid in PED itself. Saffar et al. also proposed that large PED is highly susceptible for developing RPE tear due to forces of increased hydrostatic pressure that is present inside PED (11). These authors also proposed that tear caused by large PED may be the result of rupture of RPE at the weakest point near the base of the PED. Two types of repair process after RPE tear are observed (14). It seems that persistent subretinal fluid after tear leads to subsequent repair with thickening of proliferative tissues at the area of RPE defect. Other possible mechanism of repair is complete resolution of the fluid and direct attachment of outer retina and Bruch membrane (14).

In the case of the patient with osteoma, PED was also present. However, the risk factor for tear of pigment epithelium may rather be neovascular membrane. Present dark lines on fundus color photography, and infrared images can be factors for prediction of RPE tear. Spaide et al. assumed that 
contracture of CNV adherent to the undersurface of the RPE applies traction at the junction of the attached and detached RPE which represents the weakest point (15). The force of CNV is acting perpendicular on RPE (Figure 2).

In the case of the patient with IPCV, PED is not large, but RPE tear was located in foveal and parafoveal zone, which caused low central visual acuity (Figure 3). Sudden visual loss may be explained by newly developed CNV. It has been reported that inverse relationship between the duration of the PED and a risk for RPE tear is caused by vascularized PED $(9,11,16)$. A short duration of PED means that the neovascular process is new with immature vessels. Immature vessels are more vulnerable and susceptible to anti-VEGF therapy (16).

\section{Conclusion}

So, to conclude, different eye disorders can be complicated with tear of retinal pigment epithe- lium. Treatment and outcome depend on the cause of tear. In the large, PED, specially associated with CNV, may predict development of RPE tear as well as an atrophy of RPE. Duration of PED is important for preservation of visual acuity. Therefore, it should be counseled and monitored for this complication, which may limit visual prognosis.

\section{Acknowledgement}

Authors declare no financial support.

\section{Conflict of Interests}

No conflict of interests

\section{Declaration of Funding Sources}

We declare no funding sources.
1. Strauß O. Pharmacology of the retinal pigment epithelium, interface between retina and body system. Eur J Pharmacol 2016;787:84-93. [CrossRef] [PubMed]

2. Lim JI, Lam S. A retinal pigment epithelium tear in a patient with angioid streaks. Arch Ophthalmol 1990; 109:1672-4. [CrossRef] [PubMed]

3. Levin LA, Seddon JM, Topping T. Retinal pigment epithelial tears associated with trauma. Am J Ophthalmol 1991;112:396-400. [CrossRef] [PubMed]

4. Gass JDM. Retinal pigment epithelial rip during krypton red laser photocoagulation. A Ophthalmol 1984;98:700-6. [CrossRef] [PubMed]

5. Gelisken F, Indhofen W, Partsch M, Schneider U, Kreissig I. Retinal pigment epithelial tear after photodynamic therapy for choroidal neovascularization. Am J Ophthalmol 2001; 131:518-20.

[CrossRef] [PubMed]

6. Pece $A$, Introini $U$, Bottoni $F$, Brancato $R$. Acute retinal pigment epithelial tear after photodynamic therapy. Retina 2001;21:661-5. [CrossRef] [PubMed]

7. Goldstein M, Heilweil G, Barak A, Loewenstein A. Retinal pigment epithelial tear following photodynamic therapy for choroidal neovascularization secondary to AMD. Eye 2005; 19(12):1315-24.

[CrossRef] [PubMed]

8. Coscas G, Koenig F, Soubrane G. The pretear characteristics of pigment epithelial detachments. Arch Ophthalmol 1990;108:1687-93. [CrossRef] [PubMed]
9. Christoph R, Eter CE. Retinal Pigment Epithelium Tears: Risk Factors, Mechanism and Therapeutic Monitoring. Ophthalmologica 2016;235:1-9. [CrossRef] [PubMed]

10. Doguizi S, Ozdek S. Pigment epithelial tears associated with anti-VEGF therapy: incidence, long-term visual outcome, and relationship with pigment epithetlial detachment in age-related macular degeneration. Retina 2014;34:1156-62. [CrossRef] [PubMed]

11. Sarraf D, Joseph A, Rahimy E. Retinal pigment epithelial tears in the area of intravitreal pharmacotherapy: risk factors, pathogenesis, prognosis and treatment (an American Ophthamology Society thesis). Trans Am Ophthalmol Soc 2014;112:142-59. [PubMed]

12. Guber J, Praveen A, Saeed MU. Higher incidence of retinal pigment epithelium tears after ranibizumab in neovascular age-related macular degeneration with increasing pigment epithelium detachment height. $\mathrm{Br}$ ] Ophthalmol 2013;97:1486-7. [CrossRef] [PubMed]

13. Chan A, Duker JS, Ko TH, Schuman J, Fujimoto J. Ultra-high resolution optical coherence tomography of retinal pigment epithelial tear following blunt trauma. Arch Ophthalmol 2006;124:281-2. [CrossRef] [PubMed]

14. Mukai R, Sato T, Kishi S. Repair mechanism of retinal pigment epithelial tears in age-related macular degeneration. Retina 2015; 35: 473-80.

[CrossRef] [PubMed] 
15. Spaide RF. Enhanced depth imaging optical coherence tomography of retinal pigment epithelial detachment in age-related macular degeneration. Am J Ophthalmol 2009; 147:644-52. [CrossRef] [PubMed]
16. Clemens CR, Bastian N, Alten F, Milojcic C, Heiduschka $\mathrm{P}$, Eter N. Prediction of retinal pigment epithelial tear in serous vascularized pigment epithelium detachment. Acta Ophthalmol 2014; 92: 50-6.

[CrossRef] [PubMed]

Prikaz bolesnika

UDC: $617.735-053.6 / .81$

doi: 10.5633/amm.2020.0119

\title{
RASCEP PIGMENTNOG EPITELA RETINE KOD MLADIH PACIJENTA - UZROCI I POSLEDICE
}

\author{
Sonja Cekić1,2, Jasmina Đorđević-Jocić1,2, Branislav Tomašević1 ${ }^{1}$, Ivan Jovanović3, \\ Predrag Jovanović1,2, Milena Vujanović ${ }^{1}$
}

${ }^{1}$ Klinika za očne bolesti, Klinički centar Niš, Srbija
2Univerzitet u Nišu, Medicinski fakultet, Katedra za oftalmologiju, Niš, Srbija
${ }^{3}$ Univerzitet u Nišu, Medicinski fakultet, Katedra za anatomiju, Niš, Srbija

Kontakt: Sonja Cekić

Bulevar dr Zoran Đinđić 48, 18000 Niš, Srbija

E-mail: sonjaziv@yahoo.com

Cilj rada je prikaz tri različita slučaja bolesnika sa rascepom pigmentnog epitela: bolesnika sa dijagnozom osteoma, bolesnika sa centralnom seroznom retinopatijom (CSHR) $i$ bolesnika sa idiopatskom polipoidnom vaskulopatijom (IPCV). Urađena fotodokumentacija, fluoresceinska angiografija optička koherentna tomografija (OCT) i optička koherentna angiografija (OCTA) dokazala su horoidalnu neovaskularizaciju (CNV) kod bolesnika sa osteomom i bolesnika sa dijagnozom IPCV. Kod bolesnika sa CSHR istim dijagnostičkim metodama dokazana je i potvrđena velika ablacija RPE (PED) bez CNV. Rascep retinalnog pigmentnog epitela bio je prisutan kod svih prikazanih bolesnika.

Rascep RPE može se sresti kao komplikacija kod različitih oboljenja oka, nakon ablacije RPE. Velika ablacija RPE, po visini i dijametru, zatim udruženost sa CNV, mali odnos CNV i PED, kao i dužina trajanja PED, mogu ukazivati na razvoj rascepa RPE. Zato je neophodno stalno i obazrivo praćenje nastanka ove komplikacije. Lečenje kao i ishod zavise od uzroka.

Acta Medica Medianae 2020;59(1):133-138.

Ključne reči: retinalni pigmentni epitel, rascep, uzroci 